\title{
Deconvolution法を用いた長周期波の 水位波形推定法に関する研究 APPLICATION OF DECONVOLUTION INTERFEROMETRY TO AN INFRAGRAVITY WAVE FIELD
}

\author{
小林雄一 1 ・泉宮尊司 2 \\ Yuichi KOBAYASHI and Takashi IZUMIYA \\ 1正会員 修(工) 東亜建設工業株式会社 横浜支店（广231-8983 横浜市中区太田町1-15番地） \\ 2 正会員 工博 新潟大学教授 工学部建設学科（广950-2181 新潟市西区五十嵐2の町8050番地）
}

\begin{abstract}
The deconvolution interferometry is applied to estimate wave profiles of infragravity waves propagating in intermediate water depths near and in a port. The method of deconvolution interferometry is used for estimating the impulse responses and has an advantage that remove the effect of source function, whereas the cross-correlation interferometry depends on the power spectrum of the source function. The wave profiles of infragravity waves are estimated with the deconvolution interferometry and compared with the cross-corelation interferometry. The deconvolution method produce better results for wave profiles of infragravity waves than cross-correlation interferometry.
\end{abstract}

Key Words : infragravity wave, cross-correlation Interferometry, Green function, deconvolution Interferometry, source function

\section{1. はじめに}

高波浪中に存在する長周期波は，海岸付近におい て増幅し，波の遡上・越波や浮遊砂の移動に大きな 影響を及ぼすだけでなく，港湾内において多重反射 を繰り返し減衰することなく存在し続けるために, 荷役の大きな障害となっている. 長周期波の発生要 因に関しては様々な要因が挙げられているが，現地 海岸では複数の要因が共存して作用している可能性 があり，その要因を明確に提示するには至っていな い。また，拘束長周期波については，波高やスペク トルの推定は中畑ら ${ }^{1), 2), 3)}$ により行われているが，長 周期波の入射方向や位相が不明なために自由長周期 波の波形予測までには至っていなかった．泉宮ら は干渉合成法を用いて自由長周期波の波形推定を行 い, 長周期波の水位波形推定に有効であることを示 した。これは，地震波干渉法(Seismic Interferometry) の考えを海洋の長周期波に応用したもので，その中 では2つの観測地点間の相互相関関数がGreen関数に 相当することを利用した相互相関法を用いた手法で ある. 長周期波の波形を予測することができれば, 船舶の動摇解析に直接用いることができ, 非常に有 用となる。ささらに近年では，相互相関法よりも Deconvolution法と呼ばれる手法を用いた地震波干涉 法の方が，減衰系媒質の中でも適用でき，より高精
度の物理探查ができる可能性があることが明らかに なりつつある。

そこで本研究では，Deconvolution法を用いた干 涉合成法により長周期波の水位波形推定を行い, 相互相関法によるものと比較・検討し, 水位波形推 定の高精度化を目指すことを研究の目的とする。

\section{Deconvolution法を用いた長周期波の水位波形推定法}

地震波干渉法は, 地震波等の波動場を異なる 2 地 点で観測した場合，それらの観測波形の相互相関関 数を求めると, 一方を仮想的な震源に他方を受信点 とした場合の波形を合成できるというもので，精度 の高い物理探査が行えるとして注目を浴びている5)。

しかしながら，相互相関法を用いた地震波干涉法 では，観測記録に含まれる震源関数の影響を受けた Green関数が得られ，㛜密なGreen関数を得るには 震源関数が既知でなければならなかった。これに対 し, 相互相関法で得られるGreen関数に震源関数の 影響を除去できるDeconvolution法により, 震源関数 が未知の場合でも適用できることが明らかになりつ つある(例えばWapenaar and Fokkema ${ }^{6), 7)}$ ).

Deconvolution法とは，画像解析などに用いられて いる技術であり，あるたたみ込み(convolution)され たものから，ノイズが加わった信号を原信号と応答 関数とのたたみ込みと見なして，原信号あるいは応 
答関数を求める操作である. なお, 海洋の長周期波 への相互相関法を用いた地震波干渉法の応用に関し ては，泉宮ら4)に示されている。

以下に相互相関法およびDeconvolution法について, その概要を説明することにする.

\section{(1) 相互相関法によるGreen関数の推定法}

ある領域 $D$ において, 波源よより生じる長周期波 が観測地点AおよびBで観測される水位変動 $\eta$ は, 波 源関数 $s(\omega)$ とGreen関数のたたみ込みで表現される とすると, 周波数領域ではそれぞれ次のように表す ことができる。

$$
\begin{aligned}
& \hat{\eta}\left(\mathbf{x}_{A}, \mathbf{s}, \omega\right)=s(\omega) \hat{G}\left(\mathbf{x}_{A}, \mathbf{s}, \omega\right) \\
& \hat{\eta}\left(\mathbf{x}_{B}, \mathbf{s}, \omega\right)=s(\omega) \hat{G}\left(\mathbf{x}_{B}, \mathbf{s}, \omega\right)
\end{aligned}
$$

ここに, $\omega$ は角周波数, 上付きhatはフーリエ変換量 であることを示し，

$$
\hat{\eta}\left(\mathbf{x}_{A}, \mathbf{s}, \omega\right)=\int_{-\infty}^{\infty} \eta\left(\mathbf{x}_{A}, \mathbf{s}, t\right) \exp (-j \omega t) d t
$$

であり, jは純虚数である.

ここで，2地点AおよびBで同時観測された水位変 動データに次式のように相互相関処理を施す.

$$
\begin{aligned}
\hat{C}\left(\mathbf{x}_{B}, \mathbf{x}_{A}, \omega\right) & =\hat{\eta}\left(\mathbf{x}_{B}, \mathbf{s}, \omega\right) \hat{\eta}^{*}\left(\mathbf{x}_{A}, \mathbf{s}, \omega\right) \\
& =|W(\mathbf{s})|^{2} \hat{G}\left(\mathbf{x}_{B}, \mathbf{s}, \omega\right) \hat{G}^{*}\left(\mathbf{x}_{A}, \mathbf{s}, \omega\right)
\end{aligned}
$$

ここに，*は共役複素数を示す，式(4)は，時間領域 では相互相関関数を取ることに相当する.また, 右 辺には波源関数のパワースペクトルの積で表されて いる. ここで, 次式のように全ての波源に対して積 分することで，2地点間のGreen関数が得られる.

$$
\begin{aligned}
& \oint_{\partial D} \hat{C}\left(\mathbf{x}_{B}, \mathbf{x}_{A}, \omega\right) d \mathbf{s} \\
&=\left\langle|W(\mathbf{s})|^{2}\right\rangle\left[\hat{G}\left(\mathbf{x}_{B}, \mathbf{x}_{A}, \omega\right)+\hat{G}^{*}\left(\mathbf{x}_{B}, \mathbf{x}_{A}, \omega\right)\right]
\end{aligned}
$$

式(5)において, Green関数と波源関数のパワースペ クトルの平均値の積となっており, Green関数の共 役複素数の項は非因果的な作用によるものである. この非因果的な項は原因となる事象が起こる前に結 果が起こるという因果関係が逆になっているもので, 波源がランダムに分布していればその影響は無視で きる゙).

ここで, 観測地点 $\mathrm{A}$ から地点の長周期波の水位 波形を推定する式は, 線形システムを仮定した入出 力関係式より, A地点で観測した水位変動を用いて 次式のように表わせる.

$$
\eta\left(\mathbf{x}_{B}, t\right)=K \int_{-\infty}^{t} G\left(\mathbf{x}_{B}, \mathbf{x}_{A}, t-\tau\right) \eta\left(\mathbf{x}_{A}, \tau\right) d \tau
$$

ここに, Kは推定した水位変動の振幅の大きさを補 正する比例定数であり, 本研究では波形を比較する
ために観測長周期波とパワーが等しくなるように決 定している.

\section{(2) Deconvolution 法による Deconvolution 関数の推定去}

一般に, 波源関数までも観測できるケースは数少 ないと考えられる。そこで, Vasconcelos and $\operatorname{Snider}^{8)}$ は, 波源関数による影響を除去するために Deconvolution法を用いた地震波干渉法を提案した. 2地点 $\mathrm{A} と \mathrm{~B} の$ Deconvolution関数は,

$$
\hat{D}\left(\mathbf{x}_{B}, \mathbf{x}_{A}, \omega\right)=\frac{\hat{\eta}\left(\mathbf{x}_{B}, \mathbf{s}, \omega\right)}{\hat{\eta}\left(\mathbf{x}_{A}, \mathbf{s}, \omega\right)}
$$

と表される.ここで, 分母の複素共役数の積を取る と,

$$
\begin{aligned}
\hat{D}\left(\mathbf{x}_{B}, \mathbf{x}_{A}, \omega\right) & =\frac{\hat{\eta}\left(\mathbf{x}_{B}, \mathbf{s}, \omega\right) \hat{\eta}^{*}\left(\mathbf{x}_{A}, \mathbf{s}, \omega\right)}{\left|\hat{\eta}\left(\mathbf{x}_{A}, \mathbf{s}, \omega\right)\right|^{2}} \\
& =\frac{\hat{G}\left(\mathbf{x}_{B}, \mathbf{s}, \omega\right) \hat{G}^{*}\left(\mathbf{x}_{A}, \mathbf{s}, \omega\right)}{\left|\hat{G}\left(\mathbf{x}_{A}, \mathbf{s}, \omega\right)\right|^{2}}
\end{aligned}
$$

となり, 式(8)の分子部分は相互相関法と同じであ り，それを分母のパワースペクトルで除したもので ある.これにより波源関数 $s(\omega)$ の影響が除去され， 2地点間のインパルス応答をより精度良く再現でき る可能性がある。これを全ての波源に対して積分す ることでGreen関数に相当する2地点間の忘答関数が 得られる.

$$
\oint_{\partial D} \hat{D}\left(\mathbf{x}_{B}, \mathbf{x}_{A}, \omega\right) d \mathbf{s}=\oint_{\partial D} \frac{\hat{G}\left(\mathbf{x}_{B}, \mathbf{s}, \omega\right) \hat{G}^{*}\left(\mathbf{x}_{A}, \mathbf{s}, \omega\right)}{\left|\hat{G}\left(\mathbf{x}_{A}, \mathbf{s}, \omega\right)\right|^{2}} d \mathbf{s}
$$

式(9)の実際の計算に関して, 計算の安定化を図る ために，ホワイトノイズとして地点Aにおける水位 変動の平均パワースペクトルの $10 \%\left(\varepsilon^{2}=0.1\right)$ を与え た次式を用いた。

$$
\hat{D}\left(\mathbf{x}_{B}, \mathbf{x}_{A}, \omega\right) \approx \frac{\hat{\eta}\left(\mathbf{x}_{B}, \mathbf{x}, \omega\right) \hat{\eta}^{*}\left(\mathbf{x}_{A}, \mathbf{x}, \omega\right)}{\left|\hat{\eta}\left(\mathbf{x}_{A}, \mathbf{x}, \omega\right)\right|^{2}+\varepsilon^{2}\left\langle\left|\hat{\eta}\left(\mathbf{x}_{A}, \mathbf{x}, \omega\right)\right|^{2}\right\rangle}
$$

長周期波の水位波形推定には，相互相関法と同様 に式(6)の右辺のGreen関数の代わりにDeconvolution 関数を用いる.

\section{Deconvolution関数の推定結果と考察}

本研究では, 新潟県上越市の直江津港において, 2009年12月9日から2010年1月8日にかけて行われた 長周期波の観測の結果 ${ }^{4}$ を用いた。 直江津港の概略 は図-1に示寸通りであり， $\mathrm{P}_{1}$ および $\mathrm{P}_{2}$ 地点は港外で,

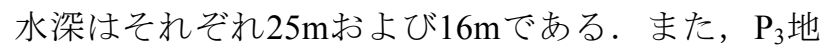
点は港外ではあるが, 防波堤の遮蔽域内で水深 $17 \mathrm{~m}$, 
$\mathrm{P}_{4}$ 地点は港内の一文字堤の端から約 $50 \mathrm{~m}$ の前面であ り，水深は $12 \mathrm{~m}$ である。また，NOWPHASによる水 深 $32 \mathrm{~m}$ 地点での観測期間中の有義波高および有義波 周期は図-2の通りであり，有義波高4mを超える波 浪が4回ほじ襲来しており，様々な波浪条件の下で 長周期波が観測されている. なお，本研究では長周 期波は周期30s〜300sのものと定義している.

1時間分の観測データを用いて，Green関数および Deconvolution関数を推定すると, 時々刻々の変動が やや大きく，これは長周期波に対して1時間では統 計的な安定性が十分には得られないことやノイズの 影響が含まれていると考えられる。そこで本研究で は, ランダムノイズを除去するために1時間分の データを24時間重ね合わせることを試み, その結果 を図-3および図-4に示し，破線は包絡波形を表す。 重ね合わせを行った結果, 図-3の相互相関関数より も図-4のDeconvolution関数の方が，高周波成分が多 く含まれるものの，遅れ時間が700s以降においてノ イズ成分が減少し， S/N比が改善されてピークが見 やすくなっているのがわかる。このピークが出現す る時間は，長周期波が 2 地点間を伝播する時間に相 当し，これらを詳しく調べることで長周期波の伝播 経路および反射位置が同定できる.

$180 \mathrm{~s}$ 前後のピークは $\mathrm{P}_{1}$ 地点から $\mathrm{P}_{3}$ 地点へ伝播する 時間であり，かなり沿岸方向に近い方向にも長周期 波が伝播しているのが分かる.さらに，0s〜100sで も相関がやや高く, 岸沖方向に伝播する長周期波も 確認され, 長周期波の方向分散性が存在しているこ とが分かる。また，280sおよび400s程度のピークは，

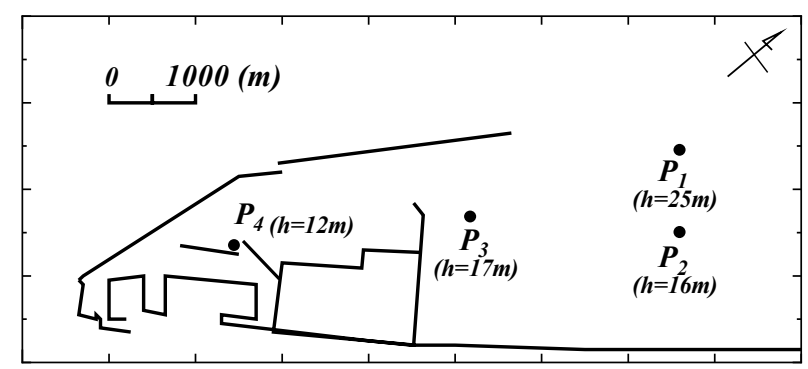

図-1 直江津港内外の長周期波観測地点

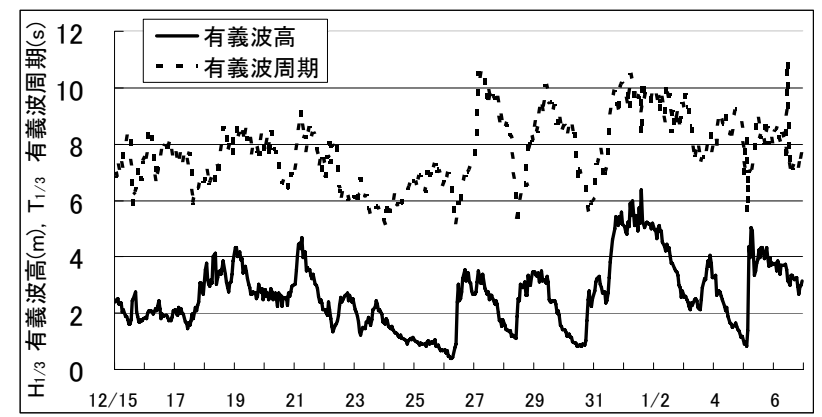

図-2 有義波高および有義波周期の変化(NOWPHAS)

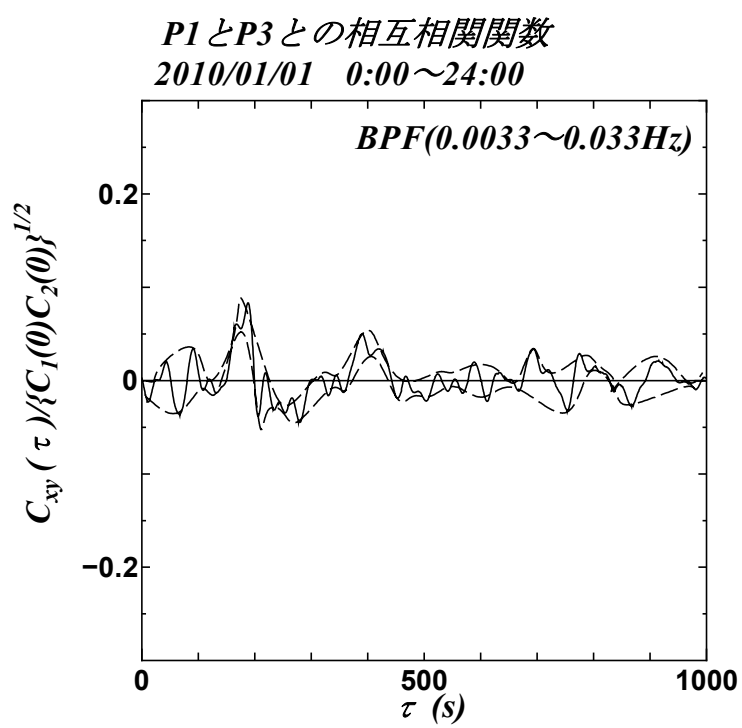

図-3 $\quad \mathrm{P}_{1}$ と $\mathrm{P}_{3}$ 地点の相互相関関数

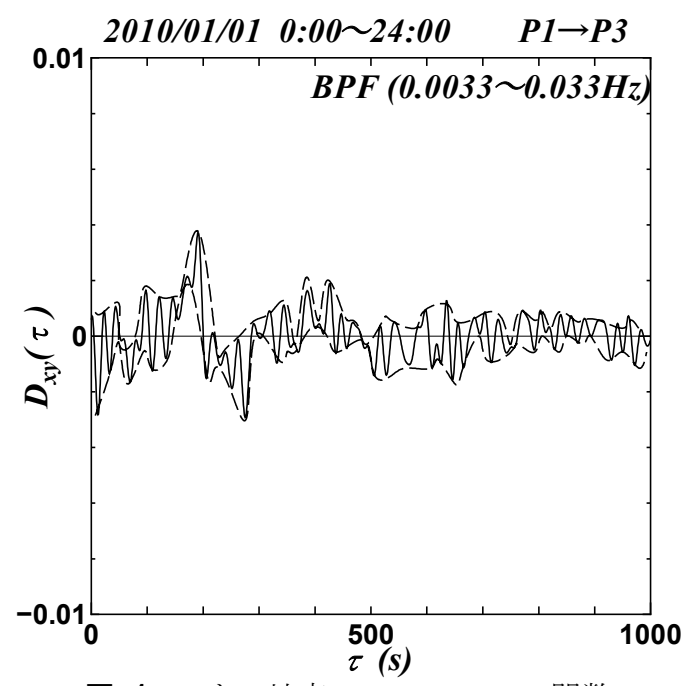

図-4 $\quad \mathrm{P}_{1}$ と $\mathrm{P}_{3}$ 地点のDeconvolution関数

それぞれ砕波点および汀線で反射してから $\mathrm{P}_{3}$ 地点へ 伝播する時間に相当すると考えられる.

\section{4. 長周期波の水位波形の推定結果と考察}

ここでは，1時間のデータより Deconvolution関数 を評価し, 長周期波の水位波形の推定を行う。本研 究では, 一番沖側の $\mathrm{P}_{1}$ 地点の観測水位変動を用いて, $\mathrm{P}_{1}$ 地点から各地点の水位波形を推定している。

図-5は， $\mathrm{P}_{4}$ 地点の水位波形を推定したものであり， 実線は観測長周期波を, 一点鎖線はDeconvolution法 による推定結果を示す. $\mathrm{P}_{1}$ 地点と $\mathrm{P}_{4}$ 地点では直線距 離にして約 $5.5 \mathrm{~km}$, さらに $\mathrm{P}_{4}$ 地点では港内における 多重反射が想定されるが，観測波形と比べると位相 もほぼ一致しており, 精度良く推定されているのが 分かる.また, 式(10)中の $\varepsilon^{2}$ の值を変化させても推 定波形への寄与は小さいことを確認している. 図-6 は， $\mathrm{P}_{4}$ 地点において港内共振が発達しているケース の水位波形の推定結果である。この場合にも位相が 


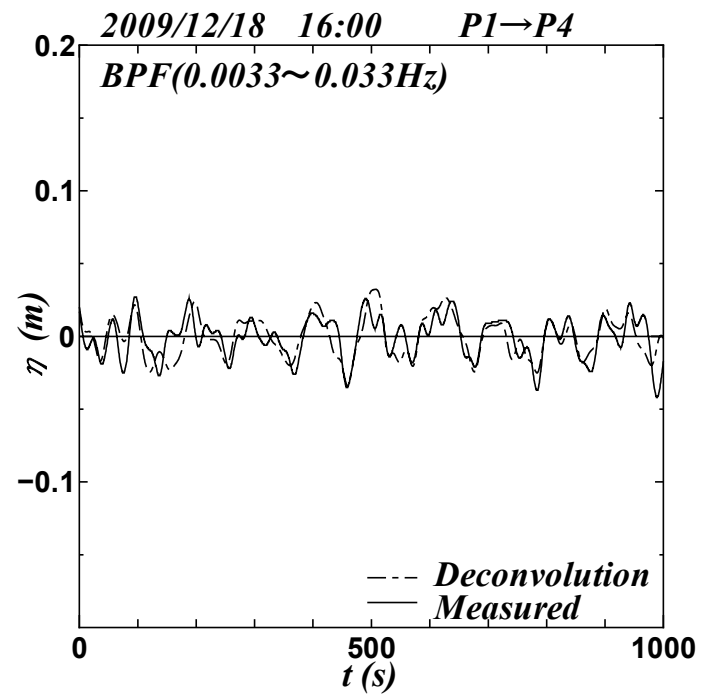

図-5 $\quad \mathrm{P}_{4}$ 地点の長周期波の水位波形推定

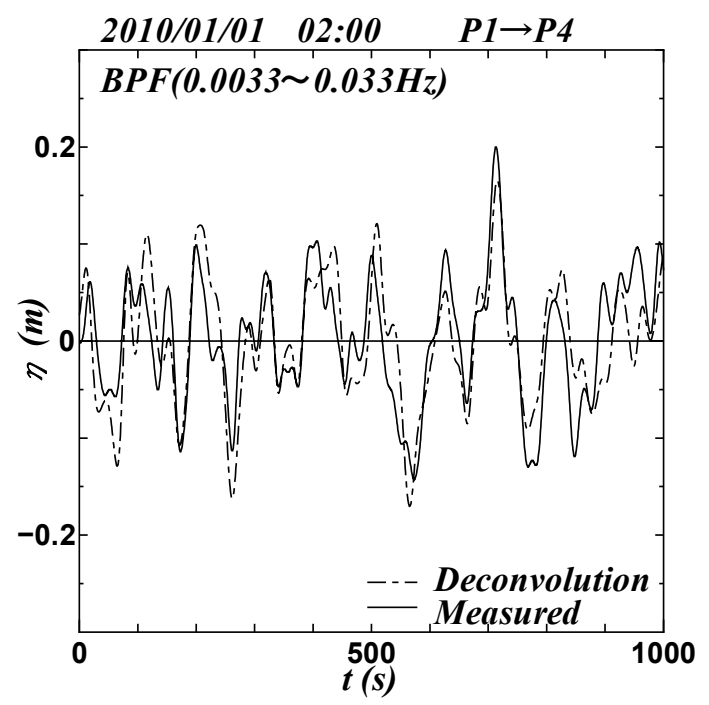

図-6 $\mathrm{P}_{4}$ 地点の長周期波の水位波形推定 (港内共振時)

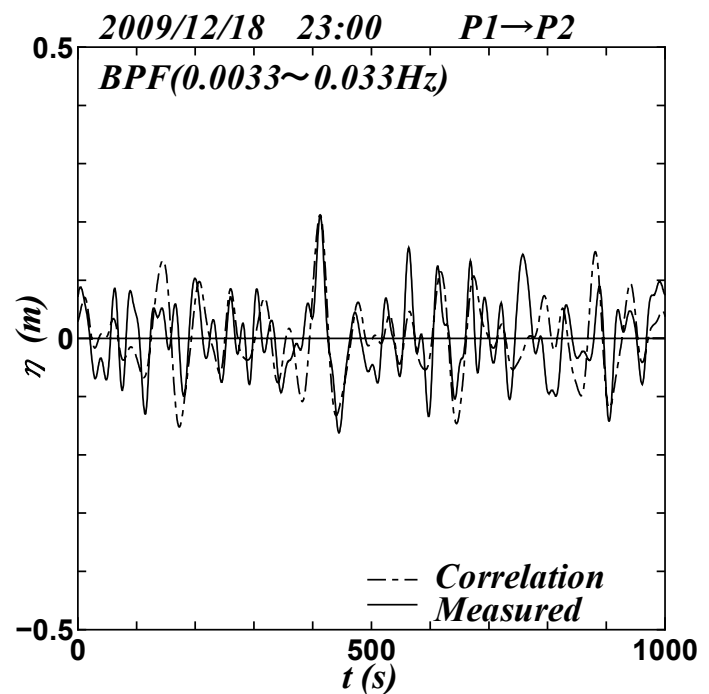

図-7 相互相関法による $\mathrm{P}_{2}$ 地点の水位波形推定

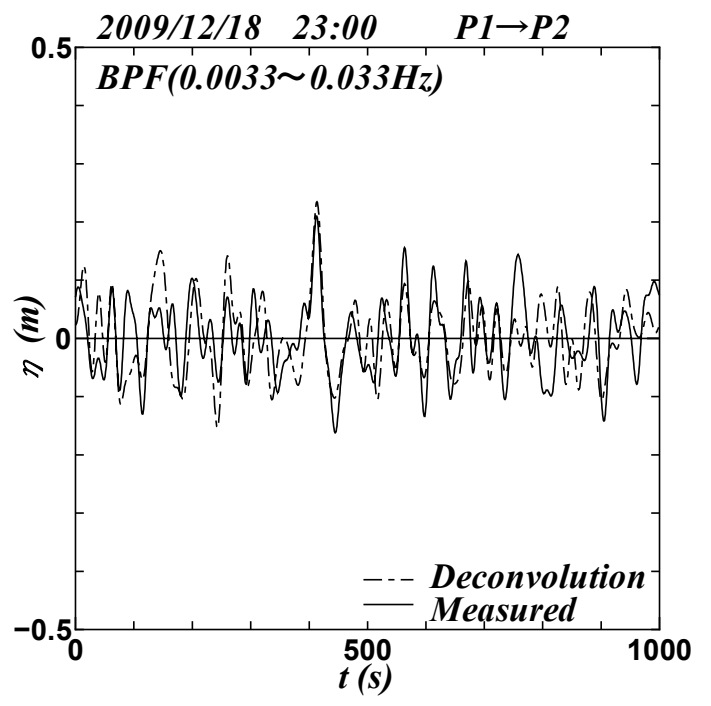

図-8 Deconvolution法による $\mathrm{P}_{2}$ 地点の水位波形推定

ほぼ合っており，共振が発達している場合でも本手 法は有効であることが確認できた。また，約700sに 現れた大きな水位変動も再現できている.

図-7および図-8は，それぞれ相互相関法および Deconvolution法による $\mathrm{P}_{2}$ 地点の水位波形の推定結果 を示す. $\mathrm{P}_{1}$ 地点と $\mathrm{P}_{2}$ 地点では約 $1 \mathrm{~km}$ 離れている。大 きな水位変動も再現できており，全体的には両手法 とも精度良く推定することができているが，650s〜 700sではDeconvolution法による方が細かい水位変動 の変化を再現できていることが分かる。

長周期波の水位波形推定において, 推定地点に よって推定精度に傾向が見られ，精度が良い順に $\mathrm{P}_{4}$, $\mathrm{P}_{2}, \mathrm{P}_{3}$ 地点となった。 $\mathrm{P}_{4}$ 地点の推定精度が良いのは, 汀線や砕波点での反射波の影響が小さく，また $\mathrm{P}_{1}$ 地 点との距離が一番遠く，防波堤の影響により 2 地点 間の伝播経路の方向がある角度に限定されているこ とに起因している可能性があると考えられる。

\section{5. 長周期波の水位波形の予測結果と考察}

水位波形の再現において比較的精度の良かった $\mathrm{P}_{4}$ 地点の水位波形の予測を行う。1時間分のデータを 用いて推定した相互相関関数およびDeconvolution関 数は，先に述べた通りに時々刻々の変動がやや大き く, 波形推定に常時用いることは難しいと考えられ る，そこで本研究では，高波浪が落ち着いて有義波 周期が長く, かつ風が比較的治まっている時間帯に おいて，1時間分のDeconvolution関数を12時間分重 ね合わせたDeconvolution関数を用いて，長周期波の 波形予測を行うことにする。これにより，ランダム なノイズ成分の影響が軽減され，長周期波に対する 統計的な安定性が確保された応答関数により長周期 波の水位波形を予測できる可能性がある。実際に用 いた相互相関関数およびDeconvolution関数は，1月3 日午前 0 時〜 12 時の時間帯のものを重ね合わせて推 定している。 


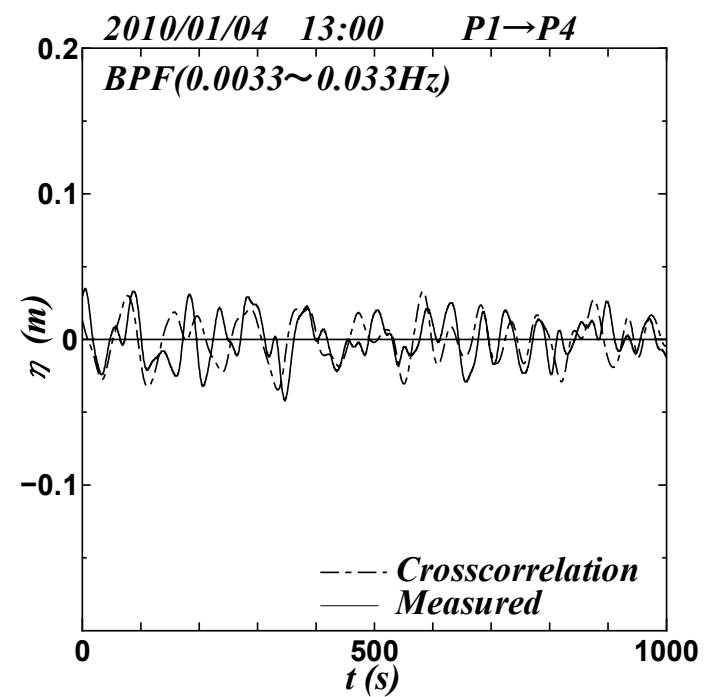

(a) $H_{1 / 3}=1.65 \mathrm{~m}$

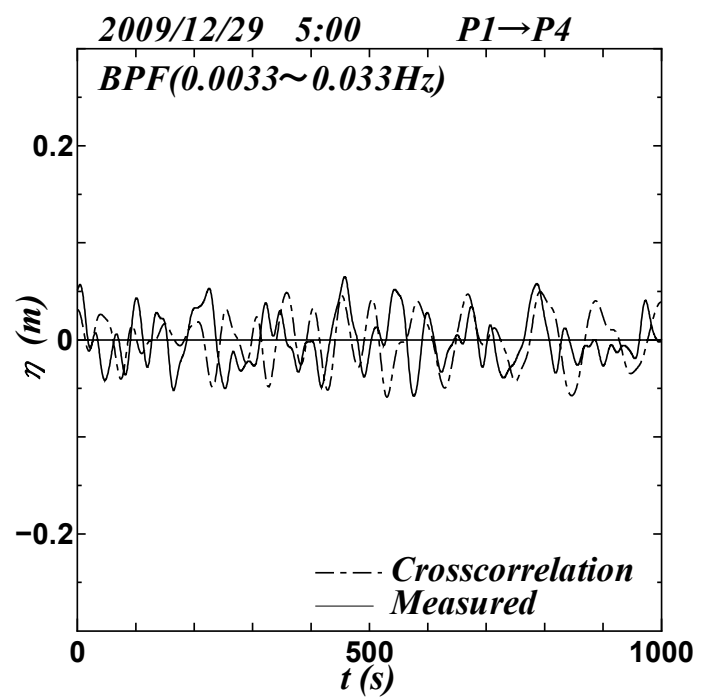

(b) $H_{1 / 3}=3.27 \mathrm{~m}$

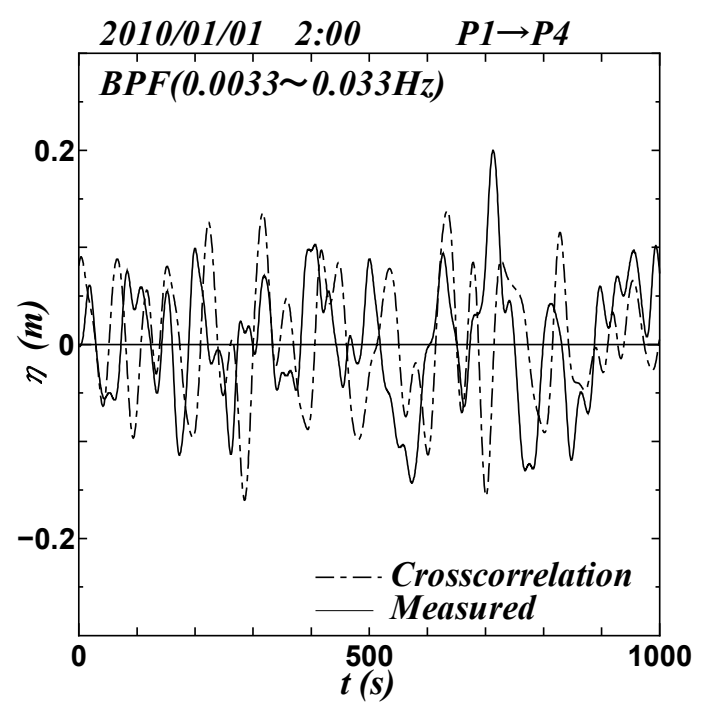

(c) $H_{1 / 3}=5.38 \mathrm{~m}$

図-9 相互相関法による長周期波の水位波形推定

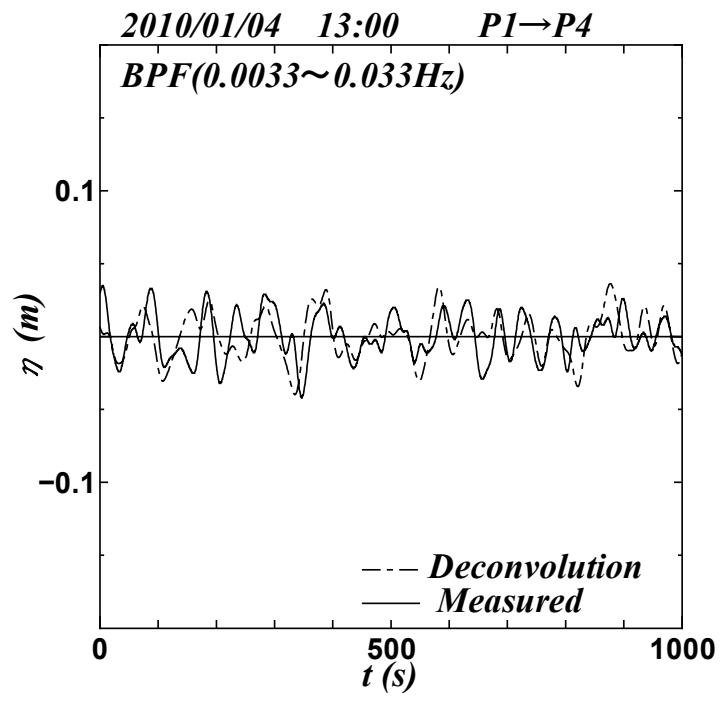

(a) $H_{1 / 3}=1.65 \mathrm{~m}$

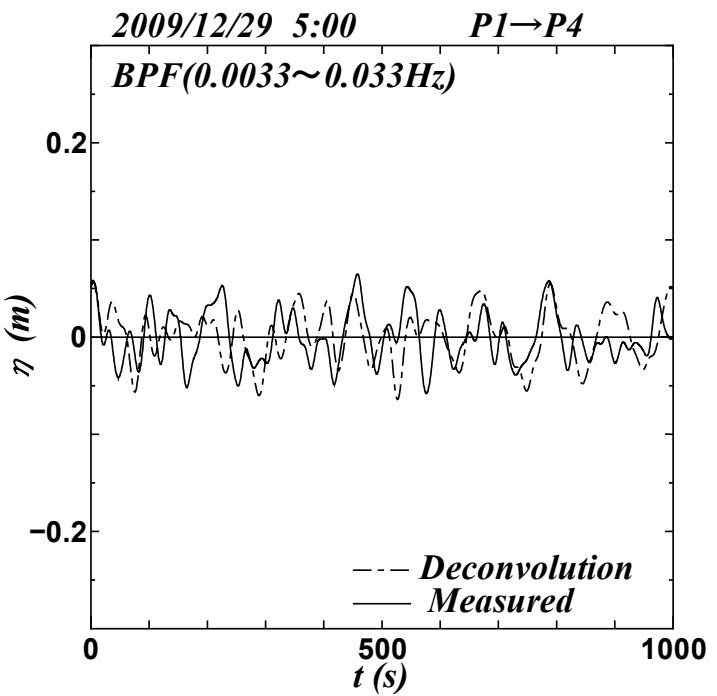

(b) $H_{1 / 3}=3.27 \mathrm{~m}$

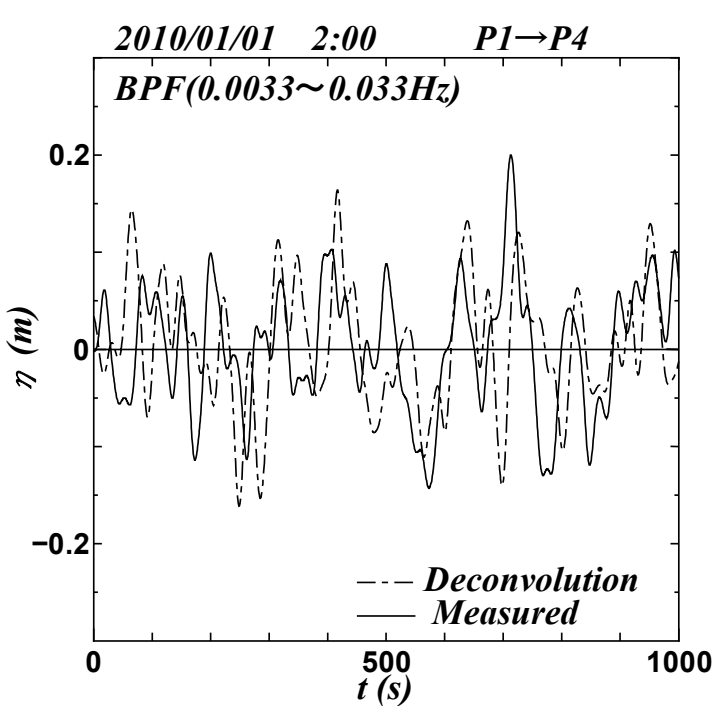

(c) $H_{1 / 3}=5.38 \mathrm{~m}$

図-10 Deconvolution法による長周期波の水位波形推定 
図-9および図-10は，それぞれ相互相関法および Deconvolution法により港内の $\mathrm{P}_{4}$ 地点の長周期波の水 位波形を推定したものである。ここに，有義波高が (a) $H_{1 / 3}=1.65 \mathrm{~m}$, (b) $H_{1 / 3}=3.27 \mathrm{~m}$ おび(c) $H_{1 / 3}=5.38 \mathrm{~m}$ の場合における両手法の比較を行う。

有義波高が(a) $H_{1 / 3}=1.65 \mathrm{~m}$ 時の水位予測結果を比 ベると，両手法とも位相は観測波形と良く合ってい ることが確認でき，両手法とも良く似た予測結果が 得られていることが分かる。

次に, (b) $H_{1 / 3}=3.27 \mathrm{~m}$ ケースでは, 両手法とも 観測波形と似た傾向を示していることが見て取れる 波形変化に誤差が生じていることが見られているが, その前後に観測波形と良く似た波形があり，位相だ けが前後していると考えられる。これは，用いた応 答関数を推定した時間帯と予測した時間帯では，長 周期波の振幅および伝播方向が異なるために，それ に伴いGreen関数も多少変化することが原因となっ ていると考えられる。

高波浪時の(c) $H_{1 / 3}=5.38 \mathrm{~m}$ のケースでは, 誤差が 生じているものの，波形変化の傾向は似ていると思 われる。これは風速 $10 \mathrm{~m} / \mathrm{s}$ を超える強風が吹いてい る場合であり，風速および圧力変動によって長周期 波が発達していることが想定される.

これらより，重ね合わせを行った Green 関数を用 いて長周期波の水位波形の予測を行った結果, 両手 法とも予測結果の精度はやや劣るものの, 比較的風 速が小さく波浪変化が小さい場合には，振幅および 波形の傾向は良好に予測できていることが分かった。

\section{6. 結論}

本研究では，Deconvolution法を用いた長周期波 の干涉合成法を海洋の長周期波に適用し, 長周期波 の水位波形の推定を行い, 以下の事柄が明らかと なった。

(1) 相互相関関数とDeconvolution関数を比較する と, Deconvolution関数の方が波源関数の影響を除去 でき，2地点間の長周期波の伝播経路および反射位 置を同定しやすいことが示された。

(2) Deconvolution法により，長周期波の水位波形 を推定した結果, 観測波形と比較的良く一致し, 本 手法は長周期波の推定に有効な手法であることが示 された。

（3）水位波形の推定に関して, 距離的に近い港外 地点の推定よりも，2地点の方向特性が限定された 一番遠い港内地点 $\mathrm{P}_{4}$ を推定した方が推定精度が良い 結果となった。

(4) 相互相関法およびDeconvolution法により，長 周期波の水位波形の予測を行ったところ, 両手法と
も波形の位相を比較的良く予測できており，長周期 波の水位波形予測に対しても本手法は有効であるこ とが示された。

（5）両手法を比較したところ, Deconvolution法の 方がより細かく長周期波の波形を推定することがで きていることが確認され, Deconvolution法はより精 度の良い長周期波の水位波形を推定することが示さ れた。

謝辞：本研究の一部は, 平成 22 年度科学研究費基盤 研究Cによったことを付記し, 感謝いたします。ま た, 本研究で用いた現地波浪観測データは，新潟大 学と五洋建設による合同現地波浪観測によるデータ を用いたこと, および有義波高・有義波周期につい ては, NOWPHASデータを用いたことを付記し, 関 係各位に感謝いたします。

\section{参考文献}

1) 中畑禎, 落合敏浩, 柏原裕彦, 関本恒浩, 花山格 章：冬季日本海における波浪・長周期波の現地観測, 海洋開発論文集, 第 17 巻, pp.31-36, 2001.

2) 中畑禎, 落合敏浩, 柏原裕彦, 花山格章, 森屋陽一, 関本恒浩 : 冬季日本海の現地観測に基づく浅海域一 の入射長周期波の評価, 海岸工学論文集, 第 48 巻, pp.256-260, 2001.

3) 中畑禎, 落合敏浩, 柏原裕彦, 花山格章, 関本恒 浩 : 冬季日本海の現地観測に基づく長周期波の沿岸 方向特性, 海岸工学論文集, 第48巻, pp.261-265, 2001.

4) 泉宮尊司, 小林雄一, 石橋邦彦, 関本恒浩, 高橋研 也, 若松厚, 石垣順, 井上俊二: 干涉合成法を用い た長周期波の伝播 ・ 反射特性の解明および水位予測, 海岸工学論文集, 第 66 巻(1), pp.176-180, 2010.

5) Wapenaar, K. and Fokkema, J. : Green's function Representations for seismic interferometry ,Geophysics 71(4) ,pp. S133-S146, 2006

6) Wapenaar, K. , Draganov D. , Roel Snider, D , Campman, X. and Verdel, A. : Tutorial on Seismic Interferometry : Part 1 -Basic principles and applications, Geophysics 75(5) ,75A, pp.195-209, 2010.

7) Wapenaar, K. , Draganov, D. , Roel Snider , Xander Campman , Arie Verdel (2): Tutorial on seismic interferometry : Part 2 -Underlying theory and new advances, Geophysics 75(5) ,75A, pp.211-227, 2010.

8) Vasconcelos, I. And Snider, R. : Interferometry by deconvolution, Part1-Theory for acoustic waves and numerical examples, Geophysics 73 (3) ,pp. S115-S128, 2008. 